\title{
Liturgiese handelinge stel nie vanself 'n erediens as ontmoeting met God (godsdiens) daar nie
}

\author{
B. Spoelstra \\ Dept. Diakoniologie \& Missiologie \\ Potchefstroomse Universiteit vir $\mathrm{CHO}$ \\ POTCHEFSTROOM
}

\begin{abstract}
The Afrikaans reformed churches oventhelmingly uphold the concept worship service (erediens)! and do not merely use the concept worship in their liturgy. This article challenges this concept inherited from the Aufklärung. It is argued that the concept worship service gives rise to the impression that a particular order of liturgical acts automatically. establishes or equalises what is called a worship service while in reality only a real encounter beween worshipper(s) and (jod by means of liturgy qualifies to be called worship. It is maintained that the Afrikaans tradition inherited too much of the Zwinglian emphasis placed on the edifying value of the sermon, and in this respect has deviated from the liturgy in the early churches. People therefore today do not experience w'orship but participate in the devotional attendance of a sermon. It is argued that this perception ought to be changed.
\end{abstract}

\section{Inleiding}

Wat 'n Nederlandse Hervormde predikant teen die middel van die eeu gesê het, sou ook van die situasie in die GKSA gesê kon word:

Voor dogmatiek en kerkorde heeft onder onze kerkelijke mensen altijd goede belangstelling bestaan ... Maar daarnaast viel een bijna totale afwezigheid van aandacht op te merken. wanneer het ging om de liturgie (Noordmans, 1986:45 e.v.).

1 Vir dic docleindes van hierdic artikel word dic term worship service gebruik Hoewel dic Engelse term worship en die Duits (jollesdienst algemeen gebruiklik is, is dic begrip worship service geskep binne kcrke wat aansluit by dic tradisic van Abraham Kusper (vgl vertalings van Kuyper se Onze erediensi van 1911) 
Tans keer die situasie weer eensydig om. Belangstelling vir dogma en kerkorde kwyn, terwyl 'vernuwing van die erediens' in die sentrum van belangstelling staan (Beukes, 1987; Barnard, 1988; Dressel, 1988, Laubscher, 1988; Müller, 1988; Brink, 1991). Oor die begrip erediens is egter baie geskryf en gepraat en dit skep die behoefte om oor liturgie en erediens te besin.

Die begrippe liturgie en erediens word betreklik lukraak gehanteer, van mekaar losgemaak, gekoppel, in mekaar geweef en met mekaar verwar. 'n Verskynsel word met die naam erediens sito-sito as 'n ontmoeting met God (godsdiens) gedefinieer omdat 'n sekere liturgiese orde gevolg word. Maar kan 'n erediens deur handelinge in 'n bepaalde orde noodwendig ' $n$ ontmoeting met God daarstel?

Die Christian Reformed Church (CRC) van die VSA kormespondeer konfessioneel, kerkregtelik en histories met die GKSA. In die VSA wil talle mense nie meer praat oor worship service (erediens) nie, maar oor worship experience (godsdiens). Gevolglik word in die CRC 'n neiging opgemerk "toward new pietism, toward lessening of ties to the past, toward a freedom that is based more in personal experience than on a concern for rootedness in historic Christian and reformed theology or liturgy" (Brink, 1991:14). Op hierdie pad moet liturgiese vernuwing op liturgiese chaos uitloop. Brink vrees dat

... satisfying the hunger for particular experiences ... we will be worshipping a god of our own making. An immediate experience shaped by a few local leaders can be just as problematic as being stuck in old patterns ... Personally, I would love to find a congregation that is fully contemporary, historical, multicultural, liturgical, charismatic, evangelical, and Reformed. But that will not happen until the Lord returns (Brink, 1991:14).

Sy tabelleer die groot verwarring wat reeds in die kringe van die CRC heers. Dominees maak skynbaar soos hulle wil.

Ek wil daarom krities kyk na gangbare gereformeerde literatuur en probeer vasstel wat onder erediens en liturgie verstaan word en hoe die begrippe of gebeure met mekaar in verband gebring word. Die vraag wanneer 'n ontmoeting met God plaasvind, is van kardinale belang. Tegelykertyd lê nuwer denke oor liturgie weer nadruk dat nie 'n saak soos 'n objektiewe erediens nie, maar 'n situasie waar God en volk mekaar wedersyds in die liturgie ontmoet, die kerk op aarde konkreet aanwesig en sigbaar maak. Vanuit hierdie gesigspunt word aanvaar dat liturgiese orde die mees basiese kerkorde is, soos wat die geval in 1 Korintiërs 14:40 was. 'n Mens moet daarby ook vra of die liturgiese handelinge outomaties 'n erediens daarstel.

In Duits word meesal van Gottesdienst en in Engels van worship gepraat benamings wat meer dinamies klink en ' $n$ vertikale relasie uitdruk wat die begrip erediens nie so maklik weergee nie maar eerder laat dink aan 'n fenomeen, ' $n$ 
Ding an sich. Gottesdienst en worship sê as't ware wat gebeur: dit dui die akte, die liturgiese handelinge aan. Die begrip worship service (Brink, 1991:14) onder Engelstalige gereformeerdes word geskep om erediens of die geheel van handelinge onder ' $n$ noemer saam te vat. Die begrippe erediens en liturgie en hoe hulle in verband staan, moet dus aandag geniet.

\section{Die begrippe erediens en liturgie}

\subsection{Die begrip erediens}

Dit is opmerklik dat die rasionele abstraksie en min of meer statiese begrip erediens (worship service) aan die Skrif onbekend en uit die Aufklärung gebore is (vgl. Barnard, 1981:58; Bakhuizen van den Brink, 1986:252, 276).

Die wyse waarop die begrip erediens gehanteer word, dui op iets selfstandig wat met bepaalde elemente gekonstrueer word ("hoekstene" - vgl. Müller, 1988: Inhoudsopgawe). Gevolglik is boeke geskryf oor Onze eredienst (Kuyper, 1911) Die erediens (Du Toit, 1977 en Barnard, 1981) en Die erediens as fees (Müller, 1988). In die GKSA word vrywel algemeen gepraat van die erediens en sy "liturgiese orde" (GKSA, 1985:404), of van byvoorbeeld "twee eredienste per Sondag". In Nederland is "bezinning op de eredienst" (Deddens, 1981) en "gesprekken over de eredienst" (Jonker, 1962) goed bekend. Bloot fenomenologies beskou, beteken erediens omtrent dieselfde as 'n ordelike byeenkoms van ' $n$ "besondere" Christelike gemeente (Beukes, 1987:20-21) of 'n afgeronde geheel van liturgiese handelinge wat geidentifiseer word as die doel van die handelinge asof die doel vanself bereik word. Vir Müller het die erediens vanself bepaalde wesenstrekke (1988:8 e.v.).

Skrywers oor die erediens sê dat dit 'n produk is van die geskiedenis (Dressel, 1988:2), en dat daarvoor uit die Skrif sekere "beginsels" afgelei kan word (Dressel, 1988:1), die erediens het 'n verbale en nie-verbale inhoud om aan te bied (Laubscher, 1988:25, Barnard, 1988:46 e.v.), dit kan soos die kerk vernuut word (Laubscher, 1988:15). Verder word gesê dat die erediens en gemeente byeenhoort, teen 'n erediens kan legitieme kritiek ingebring word (Barnard, 1988:36, 39), die erediens het 'n "wese" (Barnard, 1988:40; Beukes, 1987:17-23), die erediens kan in 'n koue, fonnalistiese byeenkoms ontaard (Beukes, 1987:3) Beukes (1987:3) stel dat die erediens die kompleks van woorde en handelinge is waarmee die Christelike gemeente sy geskenkte geloof vertolk en dus het die erediens ' $n$ bepaalde vorm en bestaan dit uit liturgiese elemente en besit wesenskenmerke (Beukes, 1987:17-23). Op grond van sodanige uitsprake is daar gevolglik "erediensdeelnemers" en "handelinge van die erediens" (De Klerk, 1987: $10,18,42$ e.v.) en is die liturgie aan die erediens diensbaar. Die erediens is dus 'n objektiewe fenomeen, 'n gebeure wat deur sy agenda gestruktureer word, 'n verskynsel soos 'n konsert in sy eie reg. 
Die vraag is egter of daar van 'n statiese en objektiewe fenomeen erediens soos van 'n 'Paasfees' in die Ou Testament gepraat kan word. Stel meertallige liturgiese handelinge vanself ' $n$ erediens daar? Die antwoord op die vraag moet waarskynlik ja en nee wees. Ek meen dat liturgiese handelinge 'n erediens as doel kan hê, maar nie dat die doel noodwendig deur daardie handelinge bereik word nie. Liturgiese handelinge moet eers slaag om 'n ontmoeting tussen God en sy volk daar te stel, voordat die gebeure as 'n erediens gekwalifiseer kan word. Wanneer 'n bepaalde liturgiese orde nagekom word, of met die oog op 'vernuwing' van 'n ou orde afgewyk is, het daar ook nie vanselfsprekend 'n erediens plaasgevind nie.

Dit lyk asof die persepsie vrywel algemeen bestaan dat sekere handelinge 'n erediens outomaties daarstel en dat liturgie en erediens sinoniem is. Dressel (1988: 7) sê byvoorbeeld:

Die erediens kan so gedefinieer word: Liturgie is die ordening van die samekoms van die gemeente (met die oog op saam-doen) ... waarin die gemeente geleentheid kry om op die dinamiek van Gods Woord te reageer in aanbidding, lofprysing, geloofsbelydenis, skuldbelydenis ...

Die defmisie mag sosiologies beskryf wat gebeur, maar wek die indruk dat die vertikale dimensie op die agtergrond raak of dat God in die samekoms deur die Bybel verplaas word - asof nie God nie, maar sy Woord ontmoet word.

Die kern van die ware erediens word weergegee met begrippe soos gesprek tussen ongelyke gespreksgenote (Barnard, 1981:329; De Klerk, 1987:100) of verkeer van God en sy gemeente onder leiding van die ampte (Barnard, 1981:388; Koole, 1946:90 e.v.), koinonia of deel hê aan, verbind word aan Christus en medegelowiges (Barnard, 1981:445-448). Erediens kom neer op 'n drieërlei ontmoeting: tussen God en sy gemeente, die gemeente en hulle God en die gemeente onderling (De Klerk, 1987:44 e.v., 78 e.v., 97; De Jongh, 1985:13-16).

Worship as a meeting is a conscious, deliberate, and explicit encounter with God ... Individual, private, devotional exercises are a kind of worship vital to our spiritual well-being. But personal devotions are not corporate worship (De Jongh, 1985:14).

Die ontmoeting tussen God en volk deur middel van woorde is slegs deur die Gees in die vleesgeworde Woord Christus moontlik (De Klerk, 1987:82 e.v., 112). Graaffland stel hierdie gedagte só - (aangehaal in Barnard (1981:419):

Mijn wereld, die ik om mijzelf had heengebouwd, word geconfronteerd met Gods wereld ... wanneer ik met Hem in contact treed ... Mijn wereld blijkt nu een schijnwereld te zijn, verdorven, schlecht, zondig ... . 
Van Rongen (1990:13) trek nog 'n skerper lyn deur van "één dienst met als toppunt één liturgie, in hemel en op aarde" te praat. Hy objektiveer "een universele eredienst" waaraan ons deelneem (Van Rongen, 1990:16).

Die begrip erediens word egter ook met ander begrippe verwissel, soos "onze kerkgang" (Van Rongen, 1990:35) of "een kerkdienst" waarin 'n predikant "preekte en voorgaat" (Oskainp, 1973:111). "Een kerkdienst kan zo mooi zijn en naar vonn zo gaaf, dat het onmenselijk wordt" (Oskamp, 1973:112). Die uitdrukking kerkdiens toon dat aan erediens tog ' $n$ ander konmotasie as aan ontmoeting met God gegee word. Dié betekenis kom seker neer op 'n "belewing van kerklike bediening" (Raubenheimer, 1984:278; vgl. Nel, 1982:206-209). Nel praat van 'n "demonstratiewe waarde" (Nel, 1982:209) en Du Preez van die "sendingperspektiewe" (1992) van die erediens. Die kerklike aksente sekulariseer die begrip tog grootliks en juis daar ontspring na my mening die probleme met die 'erediens' en 'liturgie' vandag.

\subsection{Die begrip liturgie}

Hoewel aan erediens gedink mag word, verwoord teoloë dit verskillend. Wanneer die titels van verskeie teologiese publikasies oor die erediens nagegaan word, blyk dit dat nie altyd van die erediens gepraat word nie - vergelyk byvoorbeeld: De gemeente en haar liturgie (Trimp, 1983), De zin der liturgie (Koole, 1946), Liturgie (Noordmans, 1986), Kom in sy voorhowe (Jooste, 1957), Soek die Here in sy tempel ( $V$ an der Walt, 1982), De diaken in de liturgie (Kroese, 1990) of Liturgische orientatie (Jonker, 1962). Treffend is die titel In 10 His Presence (De Jongh, 1985). Hierdie titels lê meer dinamies nadruk op handelinge as op die statiese begrip erediens. Die onderskeid wat die dinamiese begrippe teenoor die meer statiese die erediens inhou, laat 'n mens reeds vermoed dat erediens en liturgie nie dieselfde is nie; tog word liturgie en erediens nie skerp onderskei nie, maar in baie opsigte vereenselwig.

Liturgie impliseer die diens aan (jod en is afgelei van volk ( $\lambda \alpha$ ós) en werk (દ̌pyov). Die kommissie vir liturgie van die CRC (1974) stel dit so: "Liturgy is what people do when they worship" (Müller, 1987:34). Die begrip liturgie ( elke gelowige binne die volk van God.

When in worship he responds to God in faith, in praise and thanksgiving as well as with love, he does so with whole his being and feels the need to express his worship, his out-going from self to God, in words and song and gesture. If it is true that man approaches God human-wise, it is also true that God has approached man in a human manner, giving himself in his incarnate Son (Crichton, 1978:10). 
De Jongh vergelyk liturgie met ' $n$ resep wat van denominasie tot denominasie verskil. Daarmee sê hy te min. Wat wel waar is, is dat "liturgy serves worship" (De Jongh, 1985:14). Die liturgie word geken aan wederkerigheid (Deddens, 1981:17), aan "ruil" (Boonstra, 1991). Daar is handelinge waarin God na mense toe kom en hulle Hom moet ontvang en daar is handelinge waarin mense na God gaan en waar Hy dit wat hulle doen of gee, moet aanneem (vgl. Hand. 2:42; 1 Pet. $2: 2,9 ; 1$ Kor. 10:16; Ps. 18). Die Engelse woord worship stam af van worthship wat beteken om waarde aan die objek van aanbidding toe te bring (Martin, 1974: 10). Mense reageer met liturgiese handelinge soos luister, aanbid, gebede, lofprys en aanroep op wat God gee. Liturgie word in praat, doen, uitroepe, musiek, danse, handklap en gebare uitgedruk (vgl. Martin, 1974:11).

Die Duitse Gottesdienst en Engelse worship sluit baie meer as die woord ere-

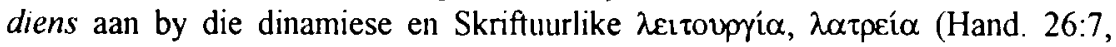

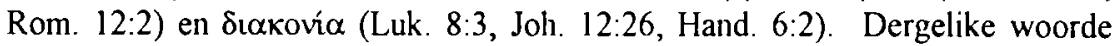
benadruk liturgie as gebeure. Godsdiens of worship vereis nie 'n erediens nie. Ek het as jong seun op Sondae boekevat (of wat godsdiensoefening genoem was) in plaashuise meegemaak en dit as direkte godsdiens ervaar, terwyl 'n 'erediens' in 'n kerkgebou by jou kan verbygaan. Godsdiensoefeninge (wat nie aan die formele begrip 'erediens' beantwoord nie) het op die grens in die VSA (Schroeder, 1966:16) en onder die Voortrekkers die behoefte aan gesamentlike aanbidding of ontmoeting met God volledig bevredig. Daaruit volg dat die handeling, die werk van die gelowige alleen, in die kleingroep of eventueel in die samekoms van die gemeente, beslissend is of God ontmoet word of nie.

Teenoor hierdie stelling kom die vraag na vore waarom daar in resente tye soveel weerstand teen die sogenaande leesdienste of ouderlingdienste ontstaan het. Sou die aksent van die Aufklärung op erediens as Ding an sich met 'n predikant wat preek (hoe belangrik ook al), godsdiens as liturgie waardeur gelowiges God ontmoet, verplaas het?

Liturgie moet pas by die aard, kultuur en geloof van die mense wat dit beoefen. Liturgie kan groei of versmoor word (Müller, 1987:34 e.v.). Sommige wil die historiese gewordenheid en ander die antropologiese vertrekpunt van liturgie verabsoluteer. Elke benaderingswyse word uit 'n bepaalde oortuiging gebore, want

... die dogmatiek bepaal die liturgie. Liturgie is uitdrukking van geloof en daarom moet alles wat in die liturgie gebeur in relasie tot geloof staan ... Liturgie is die vorm van omgang wat God self aan die mens gegee het om met Hom te verkeer. God spreek tot die mens en gee hom die mond om Hom te antwoord (Beukes, 1987:9).

Eenvoud is die mees opvallende kenmerk van die Nuwe-Testamentiese liturgie (Müller, 1988:54). Die liturgie moet altyd "'n gerigtheid, 'n gestuurdheid" hê (Müller, 1988:55). 
Calvyn het vanuit sy Christokratiese vertrekpunt die oorkoepelende doel vir menslike lewe verwoord as on God te dien en eer (Brienen, 1987:159). Daardie oorkoepelende lewensdoel trek simbolies (Burkhart, 1982:23) saam in die besondere liturgiese handelinge van gelowiges, dit wil sê "rituals, ceremonies .. reveal convictions a society has about life" (Burkhart, 1982:24). "De rechte eredienst is dan ook daar, waar ze op de eer van onze God wordt afgestemd, en waar niets met loven en prijzen van Hem in strijd is" (Brienen, 1987:160). Die liturgie kan dus as 'n erediens kwalifiseer wanneer dit sy doel bereik, naamlik om God te ontmoet. Die ontmoeting met God word egter nie outomaties deur die nakom van 'n formele "liturgiese orde" (GKSA, 1985:404) bewerkstellig nie. Liturgie is nie in die eerste plek bedoel om ' $n$ erediens daar te stel nie, maar om ' $n$ ontmoeting met God te verwesenlik. Opmerklik genoeg het Raubenheimer (1984:27; 275-290) bevind dat jongmense wat kom met die verwagting "om God te aanbid", voel dat hulle in die geloofsbelydenis betrokke is, die sang en preek "geniet", maar tog is meer as die helfte nie "tevrede" nie.

Die liturgie en behoefte om te aanbid hou nie verband met ' $n$ formele erediens nie, maar met 'n konkrete eksistensiële situasie. "Juis omdat die Gees permanent in die kerk woon, verseker die Gees 'n eenheid tussen die liturgie en die lewe van elke dag" (De Klerk, 1987:43; vgl. Barnard, 1981:46, 119, Müller, 1987:37). Die liturgie hou verband met verbondsgemeenskap as lewensgemeenskap tussen gelowige(s) en hulle Here. Sodra die verbondsgemeenskap 'n krisis beleef, bevredig die liturgie nie meer nie of die behoefte aan liturgie (godsdiens) word glad nie meer gevoel nie. Liturgie is dus nie bedoel om 'n verskynsel soos 'n erediens tot stand te bring nie, maar om 'n verband te lê tussen die lewe van elke gelowige en van die volk met hulle God. Liturgie moet dinamiese lewensgemeenskap uitdruk.

Jooste (1957:5 e.v) raak die wese van ware liturgie aan wanneer hy dit aanbidding noem - 'n baie algemene uitdrukking in die Skrif (Ps. 95:6, Matt. 4:10, Joh. 4:24; Hand. 10:26; 1 Tes. 2:3,4, Op. 13:11-18 ells.; Barnard, 1981:384 e.v., 438-442; Trimp, 1983:53 e.v.; Van der Walt, 1982:7 e.v.; Kuyper, 1911:17 e.v.; Dressel, 1988:8). Wat vandag gewoonlik 'erediens' genoem word, skiet juis ten opsigte van aanbidding dikwels ver te kort

Saamdoen in aanbidding is wesenlik baie meer as dat die gemeente net meedoen aan formele liturgiese orde of aan onderlinge opbou, 'n stigtelike Kers- of Paasprogram, gewyde sang of ' $n$ piëtistiese byeenkoms met Bybellees, getuienis en gebede (vgl. Heyns, 1903:63 e.v.). Elke kerkgeleentheid, kerkdiens of godsdienstige byeenkoms waar God in Woord en Gees na mense kom en hulle onderling opbou, hoe waardevol ook al, is nie noodwendig 'n 'erediens' wat op gesamentlike aanbidding neerkom nie (vgl. Spoelstra, 1989:357 i.v.m. begrafnisse). Sedert die Ou Testament dra liturgie wat as 'erediens' kwalifiseer 'n unieke vorm en aard op grond van die wyse waarop God by sy volk woon (De Klerk, 
1987:18-44) en hoe die ontmoeting onder leiding van verordende dienste voltrek word.

Liturgie as gebeure wat as erediens kwalifiseer, druk ware geloof uit as "a response that would result in total commitment" (Crichton, 1978:9). Die imperatief om God te ontmoet berus ten diepste op die indikatief waarin God self in sy Seun na sy uitverkore volk gekom het. Die volk 'nader' met liturgie op hulle beurt tot God wat na hulle gekom het (De Klerk, 1987:89, Heb. 10:22-25). Ons kan sê "liturgy exists to magnify the majesty and the mercy of God" (Schroeder, 1966:14; Burkhart, 1982:17-22); die liturgie druk die wil uit om God in die hele lewe met oorgawe te dien. Daarom maak die liturgie van die Vroeë Kerke wat na kommunie en eucharistie opbou, so veel sin. Eers as kommunie en eucharistie werklik plaasgevind het, het ' $n$ erediens plaasgevind.

\subsection{Liturgie moet 'n ontmoeting (erediens) daarstel}

Die werklike erediens dra die karakter van 'heiliges' wat saamkom en saamdoen

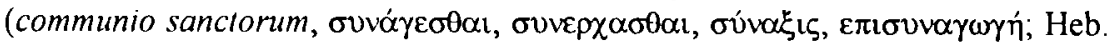
10:25; Barnard, 1981:58, vgl. Van der Walt, 1982:11 e.v). Sou almal in 'n 'openbare erediens' werklik aan 'n 'erediens' deelneem? Kan dit byvoorbeeld van elke proseliet in die Vroeê Kerke gesê word dat hy of sy in die $\sigma v^{\prime}{ }^{\prime} \xi_{1 \zeta}$ ' God ontmoet het? Is dit nie moontlik dat wat vir een erediens was vir die ander 'n blote kerkdiens was nie?

God bemiddel self deur die Gees met die Woord die ontmoeting met sy omvattende heil. Die gelowiges kan slegs deur geloof aan die heil deel kry (Bamard, 1981:429-436). Die liturgie verg van elke ware aanbidder om te glo, te beslis en om eksistensieel betrokke te wees (Crichton, 1978:9) sodat 'n erediens kan plaasvind. ' $n$ Wedersydse en lewende ontmoeting vind nie outomaties en meganies plaas nie, en sonder 'n werklike ontmoeting met die Woord en Gees kan nie van 'n erediens gepraat word nie.

Die GKSA noem in 1985 'n erediens tereg "die geestelike ontmoeting en verbondsverkeer tussen die genadige Verbondsgod en sy verloste verbondsgemeente". Die verkeer moet waaragtig, feestelik, ontdekkend, opbonend, stylvol, aktief en as 'n openbare gesprek onder leiding van die ampte verloop (GKSA, 1985:405-410). God is in en deur sy Gees en Woord teenwoordig en werksaam. Die reële teenwoordigheid van God is die uitgangspunt vir die ontmoeting (Matt. 18:20). Sonder die Woord verloop die samekoms in geesdrywery of sonder die Gees in geesloosheid. Geesloosheid kom neer op vorme en gehoor gee aan voorskrifte van ampsdraers. Geesloosheid roep om 'n reaksie van geesdrywery wat op sy beurt weer 'n reaksie van geesloosheid veroorsaak (De Klerk, 1987:1 e.v.).

Daar is ook 'n ontmoetingsaspek wat op die opbou van die gemeente gerig is, maar ook daarin is nie die gemeente nie, maar die relasie met God hoofsaak. Nie 
wie teenwoordig is nie, maar wie waarlik aan 'erediens' deelneem, ontvang volgens Brienen (1987) daaruit "vrucht en opbouw". Calvyn benadruk

... dat alles wat in de kerk geschiedt in verband moet staan met de opbouw van de geheel. ... Waar dus Christus het centrum van de aandacht en het geloven van de gemeente is en waar allen van Hem leren tot Gods eer en naar zijn wil te leven, dáár wordt de gemeente gebouwd. .... Vergeefs en zinloos is elke plechtigheid, die niet opbouwd en de ziel niet in de richting van volmaaktheid leidt (Brienen, 1987:162).

Waar werklik erediens plaasvind, bou God op deur sy Woord en Gees in geloof, hoop, liefde en werke (H.K. Son. 21, 48).

Die liturgie is ook gerig op die wêreld in so ver die gelowiges let op die wyse waarop God die wêreld bestuur. In en deur die gemeente ontmoet God ook die ongelowige wêreld, soos byvoorbeeld waar voorbidding gedoen word of die Woord of die prediking die wêreld ontdek. Kortom, die liturgie beweeg tussen die een groot koms van God in oordeel en genade na die mense en in die gaan (of nie-gaan-nie) van mense na God toe (vgl. Banard, 1981:399-403). Gevolglik bepaal die sin van die handeling en nie die praktiese handeling nie, of aanbidding en ontmoeting plaasvind. Mense haat "meaninglessness" (Burkhart, 1982:10) en soek daarom na liturgie wat op sigself (sonder voorskrifte en lesings van die 'liturg' tydens die diens) betekenisvol geskied.

Die liturgie moet daarom eenvoudig, gepas en verstaanbaar wees en die hele gemeente betrek om God deur die Woord en Heilige Gees te ontmoet. Die dinamiese begrip ontmoeting gee gevolglik die wese van 'n werklike erediens duidelik weer (vgl. Barnard, 1981:332, 371, 416 e.v.; De Klerk, 1987:19-25, 7898). God buig Hom in Christus neer om ons te ontmoet en ons moet deur die Gees uit ons wêreld opklim om God te ontmoet, te eer, te verheerlik en in gemeenskap met Hom versorg te bly (vgl. Brienen, 1987:160 e.v.).

\section{Die kerk van Christus word net in 'n ware erediens sigbaar}

Die Aufklärung het nie net die begrip erediens nie maar ook die begrip kerk gekontamineer. Mense is vandag grootskaals verwar oor wat 'kerk' is. Baie gereformeerdes kan glad nie die een kerk van Jesus Christus met die 'kerk' waaraan hulle 'behoort' of 'ons baie kerke' in verband bring nie. Hierdie verwarring is grotendeels veroorsaak toe die kerk 'as instituut' (organisasie) van die 'kerk as organisme' (gelowige mense) losgemaak is (Kuyper, 1909: 212 e.v.; vgl. Spoelstra, 1989:4-18 en 1986).

Wie die kerk as 'n Ding an sich ('n organisasie, genootskap of liggaam, struktuur, plaaslik of sinodaal) verstaan, "ontneem die kerk sy menslikheid" (Van Aarde, 
1989:325) en sy wese as eenheid van gelowige mense (Spoelstra, 1989:4-15). Gevolglik heers die sekulêre opvatting vrywel algemeen dat die kerk (hetsy plaaslik of sinodaal) as superstruktuur met sy menslose institusionele gesig die liturgie en erediens vir sy lidmate bepaal. Erediens word as 'n aktiwiteit "van die kerk as instituut", die "hart van die gemeentelike lewe en arbeid" of die "organisasiebasis vir die lewe en werk van die kerk in die wêreld" beskou (vgl. Barnard, 1981:2-4, 61 e.v., 117; Laubscher, 1988:17). In die Skrif is die samekoms van die ekklesia (erediens) egter nie 'n aktiwiteit van die kerk nie, maar die kerk self (Snyman, 1977:38; NGB 27, 28). Die sigbare ekklesia (samekoms van die gemeente) en wat ons vandag met erediens bedoel, is in die Skrif feitlik sinoniem.

Soos ons sal aantoon, maak veral die Nagmaalliturgie die kerk sigbaar. 'n Teoloog uit die Oosterse Ortodokse Kerk sê tereg:

Door de goddelijke liturgie worden wij 'kerk'... In de zondagsliturgie is de communauteit (?) een realiteit: nl. de uitdrukking bij uitstek van de lokale kerk door de aanwezigheid van Christus in de eucharistie ... Daarom is de eucharistie de voltrekking en het behoud van de eenheid van de kerk als 'mysterievol lichaam van de Heer' en 'de meest anti-individualistische handeling' van die kerk (Packstadt, 1992:114).

Ook van Rooms-Katolieke kant word na Vaticanum II oor die liturgie wat die kerk sigbaar maak, gesê:

Het gaat om de samengehouden gemeente als liturgisch symbool: juist door bijeen te komen kan zij pas echt gemeente worden en bliven (Blijlevens, 1992:243).

Die liggaam van Christus (die universele kerk) tree nêrens anders so sigbaar en so konkreet na vore as in die erediens en by name in die Nagmaal nie (vgl. Spoelstra, 1989:336 e.v.).

Müller sê: "Die erediens ... is die konkreetste antwoord op die vraag wat die kerk is" (in Barnard, 1981:63, 392). Die gereformeerdes sê dat hulle glo dat die kerk die mense is wat Christus in die eenheid van ' $n$ ware geloof vergader (H.K. Son. 21 , NGB 27-29). Ons beperk die aspek van vergader dikwels by die idee van 'n kerkstruktuur - lidmate van 'n gemeente (of selfs van 'n 'kerk'). Ons vergeet dat twee van die drie kenmerke van die ware kerk (gemeente) alles te doen het met die wyse waarop 'n gemeente op 'n bepaalde plek liturgies saamkom en doen (NGB 29; Calvyn, Institusie 4.1.9 e.v.). As die 'erediens' verval, verval die kerk as gemeente.

Vernuwing van die erediens beteken daarom vernuwing van die kerk in terme van die drie kenmerke van die ware kerk. Hervorming of venuwing van die liturgie 
moet aan die drie kenmerke van die ware kerk beantwoord. Daar is nie ' $n$ losstaande Ding an sich soos die erediens van die kerk waarvan die vonn op sigself vernuut kan word nie. Die 'erediens' is die kerk self en is erediens in so ver die kerk waarlik kerk is.

Die dogmatikus Karl Barth (1955:740) het opgemerk dat die magswerk van die Heilige Gees die gemeente na vore bring en dat 'n mens gemeente dus nie soos 'n vereniging behoort te verstaan nie. Die gemeente is nie die koninkryk van God nie, maar "das Reich Gottes ist in seiner irdisch-geschichtlichen Existenzform von Sündern verkündigt und gelaubt ... die Gemeinde" (Barth, 1955:742). "Und nun lebt ja die Gemeinde auf Erden, es lebt die communio sanctorum" (Barth, 1955: 751) en so orden Christus die kerk deur "seinen eigene Gegenwart und Herrschaft in ihrer Versammlung zum Gottesdienst" (Barth, 1955:771-800; vgl. H.K. Son. 48). Godsdiens reik natuurlik wyer as erediens (Rom. 12:2), maar erediens-liturgie bly gesamentlike godsdiens waar en in so ver die gemeente God ontmoet, dien en aanbid. 'n Mens sou dus eerder kan sê 'ek gaan kerk toe' as 'ek gaan na die erediens toe'.

\section{Liturgie is basiese kerkorde}

Hoewel die begrippe kerk, orde (Smit, 1984:6-19) en reg in die Skrif voorkom, is die begrip kerkreg omstrede omdat sowel kerk as reg sekulêr verstaan kan word (Spoelstra, 1992a). Wanneer kerkreg in die sin van God se orde (1 Kor. 14:40) verstaan word, kan gesê word dat die wortel van kerkreg geleë is in die vryheid om te dien; derhalwe is kerkreg primêr liturgies gefundeer (Barth, 1955:791, 800803). I Korintiërs 14:40 wat as locus classicus vir kerkorde dien, staan basies in verband met liturgiese orde. Pollanus se kerkorde (1551) vir die Franse vlugtelinge heet Liturgia Sacra (Noordmans, 1986:60). Micron se kerkorde in 1554 was 'n liturgiese orde (Barnard, 1981:357). Dogma, kerkorde en liturgie is in godsdiens onlosmaaklik verbonde. Belydenis is die eerste element van die Christelike godsdiens omdat dit die gemeente konstitueer. Dié eenheid word liturgies met 'n bepaalde kerkorde beleef. Die Aufklärung het finaal die betekenis van kerkorde verander, omdat dit toe as die wetlike konstitusie van 'n instituut vertolk is.

Snyman dui met goeie eksegese aan dat die plaaslike kerk (gemeente) van ware gelowiges die universele kerk (die liggaam van Christus) op daardie plek is (Snyman, 1977:45, 1966:8). Die samekoms wat ook liturgies die kenmerke van die ware kerk (NGB 29) vertoon, is die kerk van Christus op daardie plek (NGB

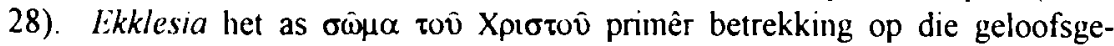
meenskap van Christene in die Nuwe-Testamentiese tyd (Van Aarde, 1989:470). Die gemeente as Bekenninisgemeinschaft, Taufgemeinschaft, Abendmahlgemeinschaft. (jehetsgemeinschaft, wat liturgiese saamwees en saandoen impliseer (Barth, 1955:793-799), maak die kerk op daardie plek sigbaar. Die liturgie wil 
dus die eenheid beleef tussen die Hoof en liggaam, Christus en sy gemeente, en dit is ook waaroor dit in goeie 'kerkreg' gaan.

Die Kerkhervonning begin in die 16de eeu by die erediens (Barnard, 1981:248 e.v.) en liturgiese oortuigings. Hoe hulle liturgies kerk wil wees, speel in die begin van die eerste GKSA in 1859/60 die aanleidende rol vir kerklike hergroepering (Spoelstra, 1990, 1992b). In die sinodale Openlike Verklaring (GKSA, 1862: art. 12) is liturgie naas leer en kerkregering die norm om kerkeenheid vas te stel en te bepaal.

Die kerk van die Here word saamgebind deur sy geloof in Jesus Christus en dit kom tot uitdrukking in die belydenis, die kerkorde maar ook in die erediens ... In 'n groot mate word die kerk kenbaar ... deur die wyse waarop die erediens ingerig word (Barnard, 1981:498).

Ek wil dit nog sterker sê: Die liturgie maak in die communio sanctorum (ware erediens) van mans, vroue en kinders die kerk van Christus op daardie plek op aarde sigbaar. "Die wese van die kerk is daarom in die grond van die saak dié van in-die-erediens-versamelde gemeente ..." (Van Aarde, 1989:470). Ware erediens is ware en sigbare kerk-wees wat per slot van sake kulmineer in verantwoorde eenheid van kommunie en eucharistie, die Nagmaal (Spoelstra, 1989: 336-337).

\section{Twee lyne in die gereformeerde liturgie}

Die liturgie van die Vroeë Christelike Kerke gaan terug op die Ou-Testamentiese tempeldiens en die sinagogekultus: in die tempeldiens staan die offer sentraal. In die Nuwe Testament sluit die sakramentele eucharistie (Luk. 22:14-22; 1 Kor. 10:16) aan by die teosentriese offer van die Pasga (1 Kor. 10:18-21). By die breek van die brood (tydens maaltye) kom die aanbidding en diensbaarheid van die volk na vore (Banard, 1981:68-78). Die sinagogediens skep 'n tweede pa-

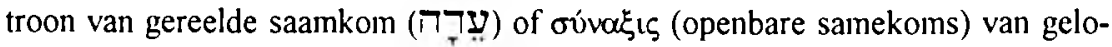
wiges, proseliete en belangstellendes met die doel on die Torah te bestudeer, die Skrifte te lees en uit te lê en om sonder offers 'n Woord- en gebedsdiens te verrig (vgl. Van Rongen, 1990:55; Banard, 1981:87-95; De Klerk, 1987:129).

Die samekomste van die gemeente in die Nuwe Testament veroorsaak in alle opsigte 'n totaal nuwe liturgie (Barnard, 1981:106-110) wat nietemin rondom die twee brandpunte van offerdiens (die Ou-Testamentiese tempeldiens) en Woorden gebedediens (die sinagoge-kultus) ontwikkel. Laasgenoemde word die inleiding tot die sakramentele (vgl. Van Rongen, 1990:46-59, 61 e.v.). In die NuweTestamentiese kerke kom die gelowiges op die eerste dag van die week (soos in die sinagoges op die sabbat) in $\sigma v_{v a k} \mathrm{k}$ van Woord- en gebedsdienste saam en die gemeenskap kulmineer in die eucharistie soos die gemeenskap tussen 
Christus en sy dissipels in die oppersaal in die Nagmaal kulmineer (vgl. Bamard, 1981:109-111; Beukes, 1987:12).

Die missa calechemenorum ( $\sigma u \dot{v a \xi}, \zeta)$ impliseer in die vroeë kerke openbare Woorddiens vir Christene, kinders en proseliete. Karel die Grote beoog volksopvoeding deur middel van 'n gerigte leerdiens wat in Duitsland rpóvows en in Frankryk $\pi$ povn' genoem word (Van Rongen, 1990:59, 91 e.v.). Die Woorddiens funksioneer as voorportaal tot die tempel, sodat Van der Leeuw dit antecommunie noem.

Na die kategumene weggestuur is, volg die eksklusiewe kommunie of eucharistie van gelowiges in die missa fidelıum. Die kommunie is selfs agter geslote deure beoefen (Van der Leeuw, 1946:133-134; Van de Pol, 1931:24 e.v.; Eber, 1991: 357-378). In die Ou Christelike vergaderruimtes het 'n kansel vir die Woorddiens en 'n vaste tafel vir Nagmaal die twee vertrekpunte vir die liturgie gevorm.

Namate die aksent al meer op die sakrament en offeridee geval het, het die altaar die kansel verdring (Van de Pol, 1931:28, 35, Brienen, 1987:149; Noordmans, 1986:135 e.v, Luiks, 1955). Die liturgie van die altaardiens word in die Missale Romanum vir die offenmis of eucharistie vasgelê, waarin die Woorddiens van die missa catechemonorum opgeneem is (Barnard, 1981:235-240, Van de Pol, 1931: 34; Van der Leeuw, 1946:133-145). Rome voeg rites toe en vertolk die mis met die transsubstansiasieleer, maar in wese bly die mis "een eerwaardig en veelzins schoon monument" (Van der Leeuw, 1946:145) waarin die oudste liturgieë van geslag tot geslag oorgedra is. Namate die humanisme aan die vooraand van die Reformasie weer soos Karel die Grote die waarde van verkondiging (leerdiens) na vore bring, neem 'n aparte $\pi$ póvaws of $\sigma 0 v^{\prime} \xi_{1 \zeta}$ in die landstaal weer vorm aan soos Surgant dit beskryf (Vall Rongen, 1990:961; Brienen, 1987:133). Bucer en Calvyn gaan anders as Zwingli met sy humanisme op die Missale Romanum terug om by die liturgie van die Vroee Kerke aan te sluit (Van der Leeuw, 1946:145; Brienen, 1987:121, 147).

Luther lê nadruk op die Woord wat die geloof werk en die gelowiges wat kragtens hulle priesterskap self op die Woord antwoord (Barnard, 1981:261-268). Daarnee plaas hy in aansluiting by die rpóvows 'n swaar aksent op die prediking. Rome en Zwingli het die eenheid tussen die twee brandpunte, kansel en tafel, Woorddiens en Nagmaal, liturgies versteur en van mekaar los gemaak en Zwingli het in die klimaat van die humanisme die Woorddiens los van die kommunie verabsoluteer. Sy invloed het 'n preekkerk teen die Roomse sakramenikerk laat ontwikkel.

Zwingli sien die mens as Platonies en hierdie gesigspunt is primêr soteriologies en sekondêr Christologies ingestel (Stephens, 1991:203 e.v., 208, 210). As humanis het Zwingli geglo in die mag van die opvoeding en die verandering van mense deur beinvloeding" (Bamard, 1981:275). Hy lê groot nadruk op die preek as 
leerdiens en sluit onder die Refornatore die meeste by die humanisme aan. $\mathrm{Hy}$ skei die Woorddiens van die Nagmaaldiens en vergeestelik die sigbare aspekte van die Nagnaal. Nagmaal word Woordverkondiging deur middel van tekens wat geestelik ontvang moet word (Stephens, 1991:203-213; Balke, 1980:152 e.v.). By Rome en Zwingli kom die Woorddiens en Nagmaal weer soos tempel en sinagoge min of meer parallel langs mekaar te staan. Die gereformeerde liturgie in Suid-Afrika sluit via Nederland grootliks by Zwingli aan (Bamard, 1981: 274; Tanis, 1991:315-323; vgl. De Jongh, 1985:28). Die sogenaamde Woorddiens kry dan later die naam van erediens terwyl daamaas kwartaalliks 'n Nagmaalsdiens plaasvind.

Zwingli verklaar gevolglik die Nagmaal vanuit Johannes 6 sodat nie die liturgie nie maar die evangelie wat die sigbare tekens vir die sondaar geestelik voorstel, beklemtoon word. Die Nagmaal word as 'n geestelike herinneringsmaal in die groot gehoorsaal gevier waar in absolute stilte die tekens as prediking die gesindheid van mense moet verander (Graff, 1951:355). Zwingli ag daarom drie of vier Nagmaalvierings per jaar voldoende (Banard, 1981:277-284, 335). In die Zwingli-tradisie val al die nadruk op die Woorddiens as erediens en periodicke Nagmaalsdienste kom los daarvan te staan.

Bucer sluit anders as Zwingli by die oorspronklike misliturgie aan en laat die Woorddiens in Nagmaalsgemeenskap kulmineer (Barnard, 1981:305). Calvyn sluit ook by eenheid tussen Woorddiens en Nagmaal aan.

Zijn liturgische orde voor de hoofdienst, d.i. de zondagmorgendienst heeft twee brandpunten: de prediking en de avondmaalbediening. Dit is de eigenlijke structuur van de Roomse, nog meer van de Oudchristelijke misliturgie - 'mis' hier in zijn originele zin verstaan- ... (Brienen, 1987:121).

Calvyn wil die Bybelse struktuur van die ontmoeting van God met sy volk in die twee-eenheid van Woord en Nagmaal vashou (Brienen, 1987:264, 137). Hy suiwer die misliturgie van alles wat dui op die offergedagte en al die ingewikkelde vormlike en nuttelose seremonies van die Roomse erediens (Brienen, 1987:147). Hy dring aan op die weeklikse diens van Woord en Tafel om "coustume de l'Eglise ancienne" by die Nuwe Testament aan te sluit (Brienen, 1987:139).

\section{Dialoog oor liturgie met die preek of Nagmaal as vertrekpunt}

Teen die middel van die 20 ste eeu het binne die Nederlandse Hervormde Kerk 'n debat oor liturgie en erediens ontstaan. Noordmans het die pronaus-rigting van Zwingli en die preek as kern van die erediens bepleit (198649, 55-57, 186 e.v.; Van der Leeuw 1986:172 e.v.). Van der Leeuw $(1946,1986)$ en andere (Van de Pol, 1986, Bakhuizen van den Brink, 1986) het luulle op die Vroeè Kerke en op Calvyn vir sakramentele liturgie beroep. Hulle wou die Woorddiens die karakter van die missa catechemenorum laat dra en as "ante-communie" vir die missa 
fidelıum (Nagnaal) laat dien (Van der Leeuw, 1946:133 e.v.; 1986:179 e.v.). Die debat is vandag nog aktueel, omdat as die vertrekpunt beteken dat die tekens Christus aan ons verkondig (Zwingli), sou ons kinders tot die Nagmaal kon toelaat en 'n oop kommunie in banke kon vier. Volgens die Zwingli-standpunt wat Nagmaal as soteriologiese verkondiging beskou, kan die Nagmaal selfs funksioneer as sendingwerk onder ongelowiges wat daar aanwesig is (Du Preez, 1992:50; vgl. "verduidelikende waarde" - Nel, 1982:209).

Die rasionalisme, Puritinisme en Nadere Reformasie het via Nederland ook ons liturgie op die preekdiens afgestem (Brienen, 1987:265, vgl. 134). Ons merk in Suid-Afrika dat die gemeente passief en in stilte die preek afwag en hoog aanslaan as die sin van die 'erediens'. Van der Leeuw (1946) waardeer onder die reformatoriese liturgieë die Anglikaanse liturgie, terwyl die Puriteine juis heftig teen dié liturgie gekant was en op innerlike ervaring, of wat vandag spirttualıteit genoem word (Juch, 1992:1), nadruk gelê het. Hulle het deelname van die gemeente aan liturgiese vonne beperk om die preek en meditasie te aksentueer, want wanneer

. sound doctrine is preached, it should somehow automatically follow that people's lives will change - an outcome not always realized. In other words, implicit in our theologizing and preaching has been certain notions concerning the primacy of the intellect (Schuringa. 1991:470).

Ons moet egter onthou dat die mens met sy emosie voondurend wat hy intellektueel meemaak, positief of negatief waardeer. Hoe hy liturgie ervaar, het gevolglik grool invloed op sy wilslewe.

Kuyper en andere praat van "valse spiritualisme" waarmee die Puriteine die breë liturgie van Calvyn en a Lasco afgewys en net op die preek, 'n enkele aspek van die liturgie, gekonsentreer het (Kuyper, 1911:36-40; Noordmans, 1986:46; Van der Leeuw, 1986:167-177; Van de Pol, 1986:203, 207, 212). Noordmans (1986: 57) fikseer op die preek omdat hy in die nadruk op liturgie 'n "dogma van de cultus, dat ons oosters aandoet", vrees. Van der Leeuw is egter oortuig dat as iemand oor die eredienst praat, praat hy oor die dogma van die kultus (1986:182, vgl. Van de Pol 1986:213). Die valse teenstelling tussen 'n intellektuele en emosionele belewing van die liturgie of 'erediens' het die gereformeerde liturgie skade gedoen. Die idee van ' $n$ "preekkerk" het wyd posgevat sodat selfs die pastoraat as 'n "sakformaat preek" beleef word (Smuts, 1971:107).

Eensydige aksent op die preekdiens as leerdiens, "limited ... to the activity of one man" (De Jongh, 1985:52), hoe belangrik ook al, verann die erediensliturgie. Wanneer die preek in die sentrum staan, kry die liturgie die skyn van ' $n$ onderriggeleentheid waarin die universiteitsopgeleide predikant dikwels onder ' $n$ akademiese toga, met 'hoorders', kommunikeer. Die liturgie draai na alles om die preek en die liturgie $k r y$ 'n eensydige didaktiese inslag (Barnard, 1981:252, 298, 
Brienen, 1987:135, 163, 166, 170). Die liturgie is 'n ontmoeting met die predikant en die lidmate ontmoet God hoogstens deur middel van die dominee. Daarteenoor ervaar kerkgangers dat hulle aan die geloofsbelydenis en sang in die liturgie werklik deel het (Raubenheimer, 1984:285), terwyl die prediking 'geniet' word (Raubenheimer, 1984:290). Brink (1991:14) stel dat as gevolg van die preek die kerkgangers se "deepened interest in experiencing emotions ... have been hindered by a too cerebral and intellectual approach to worship". Hulle soek die oplossing "in a healthy increase in congregational participation" wat selfs "audience participation" genoem word (vgl. ook Bannard, 1988:44). Hierdie weg sal egter versigtig bewandel moet word om die gevaar van verdere horisontalisering en profanisering uit te skakel omdat juis die aktiewe aanbidding daardeur verder teruggedruk kan word

Die moderne sosio-politieke prediking se aksent op die erediens as 'n geleentheid om deur die preek met God en die wêreld te kommunikeer, het die ontmoeting met God reeds op die agtergrond gedruk, terwyl 'n Rooms-Katolieke teoloog sê dat die Westerse liturgie met die nadruk op die preek gevaar loop

... dat de rijkdom en volheid ervan dreigen te worden gereduceerd tot puur 'zielzorg' of tot een louter politieke of sociaal technische aangelegenheid. Aan de ene kant word de liturgie vaak nog de enige plaats waar mensen tot zichself kunnen komen ... Aan de andere kant dreigt de liturgie steeds meer een instrument in de handen van allerlei maatschaplijk organisaties te worden, die hierin een unieke gelegenheid zien om de doelen en belangen welke zij nastreven onder de aandacht te brengen of daaraan extra kracht bij te zetten (Blijlevens, 1992:239).

Daarteenoor moet onthou word dat liturgie nog die enigste plek is waar mense tot hulleself kan kom (Blijlevens, 1992:239). Dit is opvallend hoe sosio-politieke bewegings onder swart mense in Suid-Afrika onlangs die preek en gebed gebruik het om hulle politieke offensief te orkestreer (vgl. Kairos, 1986).

'n Mens begryp dat die 'preek' vir die dominee belangrik is. Hy is spesiaal tot daardie belangrike liturgiese taak geroep. Verkondiging is van die begin af ' $n$ aspek van liturgie, maar nie die hoof- of enigste saak in die ontmoeting wat die liturgie tussen God en gemeente moet daarstel nie. Sonder om aan die preek as liturgiese moment afbreuk te doen, is dit 'n ope vraag of didaktiese gebeure ' $n$ 'erediens' kan maak. In die Nederlandse gereformeerde tradisie beteken 'ek gaan na die kerk' omtrent 'ek gaan na die preek' (en daarom verny mense 'n ouderlingdiens). Iemand uit die CRC sê: "If you shove the pulpit off to the side, you mess with what the church is all about" (Timmer, 1992:6). As hierdie stelling waar is en alles in die liturgie op preek neerkom, is die dominee ooraktief en die werk van die volk kom dan net op luister neer.

Ek meen dat ook in die GKSA te veel aanvaar word dat die preek die essense van die liturgie vorm. Die begrip 'eerste' en 'tweede' erediens sentreer moontlik om 
die idee van twee preke. Die opsomming van die preek in nuusbriewe, gestruktureerde preekbesprekings en skemas om luisteraars meer by die prediking te betrek, benadruk die preek. In die GKSA word die Skrif net met die oog op 'n preekteks gelees - oor die res van die Sondagse liturgie (gebede, gebedsliedere, kollekte, skuldbelydenis) word niks in die nuusbrief gesê nie: dit moet die indruk skep dat die begrip erediens om die preek gaan.

Die Zwingli-Puriteinse liturgie van 'n preekkerk verlê die aandag van ' $n$ direkte na ' $n$ indirekte ontmoeting met God en maak die gemeente liturgies passief - al is dit nie so bedoel nie. Die gemeente ontmoet God hoogstens middellik deur die predikant as voorbidder en prediker. Wanneer die preek die hoofmoment van die 'erediens' vorm, is daar 'n minimum liturgie (werk van die volk van God) in die ontmoeting wat erediens genoem word. Gevolglik is die preekdiens op hierdie wyse onvolledig indien dit nie kulmineer in die Nagnaalliturgie of tafeldiens nie.

\section{Slotsom}

Die gedagte van 'n erediens as Ding an sich het veral gedurende die 18 de eeu na vore gekom toe die preekdiens as leerdiens, onder invloed van die humanisme, dominant geword het. Zwingli veral het benadruk dat die preekdiens 'n leerdiens is. Met hierdie beklemtoning het die idee van liturgie verswak. In die preekkerk kom die liturgie van die volk grootliks soos in 'n klaskamer op luister en mediteer neer - aksies wat ' $n$ lae vorm van aktiwiteit en betrokkenheid kan wees, veral as die preek nie slaag nie. Met die preekkerk as vertrekpunt kan die wese van die sogenaamde erediens nie sito-sito as 'n ontmoeting met God beskryf word nie, maar sal die wese van 'erediens' vanuit die moderne aksente op gemeentebou, toerusting en inspraak van die 'lidmate' as 'opbougeleentheid' gedefinieer moet word. Allerlei skemas om 'in erediens wat so verstaan word te vernuut, kan nie deug nie.

Die volk behoort Sondae natuurlik saam te kom met die primêre doel om hulle God onder leiding van die ampte saam te ontmoet. Eers wanneer die liturgiese handelinge 'n ontmoeting tussen God en die volk voltrek, kan van godsdiens in die gestalte van 'n erediens gepraat word. Die gangbare rasionele begrip die erediens wat outomaties deur die nakom van 'n bepaalde liturgiese orde daargestel word, moet afgewys word. 'n Erediens kom nie tot stand deur 'n aantal elemente van 'n votum tot 'n slotseên te volg nie. 'n Tweede erediens (wat uit 'n leerdiens ontwikkel het) kan ook nie pas na 'n eerste met dieselfde liturgiese orde daargestel word net omdat ' $n$ ander preek gepreek word nie (omdat minstens die slotseën sy liturgiese betekenis van 'n wegstuurformule aan die einde van die eerste diens verloor). Die opvatting van die erediens as 'n objektiewe Ding an sich, as 'n gestruktureerde byeenkoms van 'n bepaalde kerklike denominasie, kan die liturgie smoor sodat die volk nie God nie, maar 'n liturg ontmoet en sodoende geen godsdiens beoefen nie. 


\section{Bibliografie}

BAKHULZEN VAN DEN BRINK, J.N 1986. Eredienst (In Hasselaar, J M et al, red Dr O. Noordmans Verzamelde Werken. Deel VI. Kampen : Kok. p. 252-262, 276-282.)

BALKE, W. 1980a De Avondmaal bij Calvijn ( $n$ Van't Spijker, W et al. red. Bij brood en beker. Kampen : De Groot Goudriaan p. 149-255.)

BALKE, W 1980b De Avondmaalsleer van Zwingli. (In Van 't Spijker, W et al. red. Bij brood en beker. Kampen : De Groot Goudriaan. p. 149-177.)

BARNARD, A.C. 1981. Die erediens Pretoria : NGKB

BARNARD, A.C. 1988. Vernuwing van die erediens Praktiese Teologie in Suid-Afrika, 6.29-62.

BARTH, K 1955. Die Kirchliche Dogmatik. Band 4. Die Lehre von der Versohnung. Deel 2. Zollikon-Zürich : Evangelischer Verlag.

BEUKES, M J du P. 1987. Vernuwing in die erediens Praktiese Teologie in Suid-Afrika, 3:1-33.

BLIJLEVENS, Ad 1992. De mens als beeld van God in de christelijke liturgie. Tijdschrift voor Liturgie, 76 (4):239-250.

BOONSTRA, H 1991 What is Worship? A Gift Exchange The Banmer, 126(17) 12-13

BRIENEN, T 1987. De liturgie bij Johannes Calvijn. Kampen : De Groot-Goudriaan

BRINK, E.R. 1991 Worship in the CRC: a Matter of Grafting The Bamer, $126(22): 12-14$

BURKHART, J.E. 1982. Worship, a Searching Examination of the Liturgical Experience. Philadelphia : Westminister Press.

CRICHTON, J.D 1978. A Theology of Worship (In Jones, C., Wainwright, E., Yarnold, S.J ed., The Study of Liturgy. London : SPCK. p. 1-30.)

DE JONGH, J.A 1985. Into his Pressence. Grand Rapids : Board of Publications CRC

DE KLERK, B J. 1987. Die Heilige Gees en die verhouding Skriflesing, prediking en gebed in die erediens. Potchefstroom: PU vir CHO (Th.D Proefskrif)

DEDDENS, K. 1981. Waar alles van Hem spreekt: bezinning op de eredienst Groningen Vuurbaak.

DRESSEL, 1988. Wat is die erediens wat vernuut moet word? Praktiese Teologie in SuidAfrika, 6:1-14

DU PREEZ, J 1992. Sendingperspektiewe in die erediens Stellenbosse Teologiese Studies: 18, 19. NG Kerkuitgewers.

DU TOIT, J.D. 1977. Totius Versamelde Werke. Deel 3 Kaapstad : Tafelberg.

EBER, HE. 1991. Abendmahlslehre - Abendmahlspraxis - Abendmahlgemeinschaft in reformierter Sicht. (In Van 't Spijker, W. red Calvin Erbe und Auftrag Kampen: Kok p. 357-378.)

GKSA. 1862. Handelingen van de eerste Algemeene Sijnodale Vergadering der Gereformeerde Kerk van de Zuid-Afrikaansche Republiek, den Oranje Vrijstaat en de Kaap-Kolonie te Reddersburg: 2-24 Maart 1862. Kaapstad: Saul Solomon

GKSA. 1985. Handelinge van die 42ste Nasionale Sinode. Potchefstroom.

GRAFF, P. 1951. Lehrbuch der Liturgik Göttingen : Vandenhoeck-Ruprecht.

HEYNS, W. 1903. Liturgiek, ten dienste van de studenten aan de Theologische School der Christelijke Gereformeerde Kerk te Grand Rapids Holland : Holkeboer.

JONKER, H. 1962. Liturgisch orientatie; gesprekken over de eredienst. Wageningen : Zomer en Keunig

JOOSTE, J P. 1957. Kom in sy voorhowe. Potchefstroom : Pro Rege

JUCH, H.T. 1992 Spiritualiteit is in Gods verborgen omgang vinden Centraal Weckblad, $40(40): 1$, Oktober

KAIROS, 1986 Kairos Liturgies Braamfontein : Southern Transvaal Kairos Liturgy Group. 
KOOLE, J.L 1946 De zin der liturgie, een boekje voor hen die belangstellen in onze kerkdienste. Amsterdam : Bakker

KROESE, J. 1990. De diaken in de liturgie Diakonia: 181-183, Sept

KUYPER, A. 1909. Encyclopaedie der Heilige Godgeleerdheid Deel III Kampen : Kok

KUYPER, A 1911 Onze eredienst Kampen : Kok

LAUBSCHER, J.A. 1988 Wie vernuwe die erediens? Praktiese Teologie in Suid-Afrika, 6: $15-28$

LUIKS, A S 1955. Cathedra en Mensa; de plaats van de preekstoel en avondmaaltafel in het oud christelijke kerkgebouw volgens opgravingen in Noord-Afrika Franeker :Wever

MARTIN, R P 1974 Worship in the Early Church Grand Rapids : Eerdmans

MULlER, J. 1987. Vastheid, variasie en kreatiwiteit in die liturgie. Praktiese Teologie in Suid-Afrika, 3:34-42.

MULLER, J. 1988. Die erediens as fees Pretoria NGKB

NEL, M. 1982. Jeug en evangelie Pretoria : NG Kerkboekhandel

NOORDMANS, O 1986. Verzamelde werken. Deel VI De kerk en het leven Kampen Kok.

OSKAMP, P. 1973. Liturgische broedplaatsen Kampen : Kok

PACKSTADT, I 1992 De liturgische beleving van de Zondag in de Orthodoxe Kerk Tijdschrift voor Liturgie, 76 (12) $112-115$

RAUBENHEIMER, O.S.H. 1984 'n Prinsipieel-empiriese ondersoek na die naskoolse jeug se belewing van die bediening van die Nederduitse Gereformeerde Kerk Pretoria : Universiteit van Pretoria (DD-Proefskrif)

SCHROEDER, F.W 1966. Worship in the Reformed Tradition Philadelphia : United Church Press.

SCHURINGA, H. 1991 The Supremacy of God in Preaching by John Piper Calvin Theological Journal, 26(2) 470-471

SMIT, C.J. 1984. God se orde vir sy Kerk - 'n bespreking oor die Kerkorde Pretoria : NG Kerkboekhandel

SMUTS, A.J. 1971. Aspekte en toepassing van die pastorale gesprek Hervormde Teologiese Stucties, 27 (3\&4): 107-120

SNYMAN, W.J. 1966. Universele en plaaslike Kerk. Die Kerkblad, 8-9, Julie 20.

SNYMAN, W J 1977. Nuwe en ou dinge Potchefstroom: Pro Rege

SPOELSTRA, B. 1986 Het ons kerkwees in strukture gestol? Hervormde Teologiese Studies, $42(1): 94-109$

SPOELSTRA, B. 1989. Gereformeerde Kerkreg en Kerkregering Hammanskraal : Hammanskraalse Teologiese Skool

SPOELSTRA, B 1991 Die begin van die Gereformeerde Kerke in Suid-Afrika 1859 tot 1860. (In Du Toit, H., Kruger, P red. Geroep tot eenheid. Halfweghuis : NG Kerkboekhandel p 143-156)

SPOELSTRA, B 1992a. Op soek na 'n duidelike reformatoriese paradigma vir kerklike gesag Hervormde Teologiese Studies, 48 (3 \& 4):901-921

SPOELSTRA, B 1992b. Secession and the Reformed (Dopper) Churches in South Africa (In Schrotenboer, PG ed Catholicity and Secession. A Dilemma? Kampen: Kok p. 148-161.)

STEPHENS, W P. 1991. The Soteriological Motive in Eucharist Controversy. (In Van 't Spijker, W red Calvin Erbe und Auftrag Kampen : Kok p 203-213.)

TANIS, J. 1991 East Friesland and the Reformation Calvin Theological Journal, 26(2): 313-349.

TIMMER, J. 1992. Revive Us Again. The Bammer, 127 (3) 6, 7.

TRIMP, C 1983 De gemeente en haar liturgie Groningen : De Vuurbaak 
VAN AARDE A.G. 1989. 'n Nuwe-Testamentiese begronding van die eenheid van die kerk en die eis om kerkeenheid vandag. Hervormde Teologiese Sindies, 45 (2):461-475

VAN DE POL, W.H 1931. Liturgie. Zeist : Ploegsma

VAN DE POL, WH. 1986. De vraag naar de liturgie krachtig aan de orde gesteld. (In Hasselaar, J.M. et al., red Dr. O. Noordmans Verzamelde Werken. Deel VI Kampen : Kok. p. 205-216)

VAN DER LEEUW, G. 1946. Liturgiek. Nijkerk : Callenbach.

VAN DER LEEUW, G. 1986 Liturgie in de crisis ( $n$ Hasselaar, JM et al., red Dr. O Noordmans. Verzamelde Werken. Deel VI Kampen : Kok p. 165-243.)

VAN DER WALT, J.J 1982. Soek die Here in sy tempel. Potchefstroom : Potchefstroom Teologiese Publikasies

VAN RONGEN, G. 1990. Met al de heiligen. Barneveld : De Vuurbaak 